\title{
Additional building rights certificates: a funding mechanism for urban partnership operations or a speculative instrument?
}

\author{
FABIO JOSÉ FERRAZ ${ }^{1}$ \\ Denio Munia Benfatti ${ }^{2}$ \\ ${ }^{1}$ Pontifícia Universidade Católica de Campinas (PuC-Campinas) / Programa de Pós-Graduação em Arquitetura e \\ URBANISMO, CAPES SCHOLARSHIP, CAMPINAS - SP, BRAZIL \\ 2 Universidade de SÃo PAUlo (USP) / FACULdAde de ARQUitetura E URBANISMo, LABORATÓRIo QUAPÁ, SÃo PAULO - SP, BRAZIL
}

\begin{abstract}
This paper presents the urban partnership operations (OUCS) as public-private alliances that generate public value developed in the context of globalization and financialization of the real estate market, fiscal constraints and primacy of private interests in the production of urban space. With the City Statute, additional building rights certificates (CEPACs) are now the OUCs main financing mechanism. CEPACs are subject to much controversy since their establishment because of a possible speculative financial component. Fifteen years after their first auctions, they must now be analysed less theoretically and based on the prices and volumes made in their negotiations. Based on the history of auctions and conversions of the OUCS Faria Lima and Água Espraiada (both from São Paulo-SP), the paper presents advances in the reflection on the real possibilities of this instrument, minimizing its speculative feature as currently predicted, and indicates the need for public governance over OUCs in relation to the generation of public value and the guarantee of the right to the city.
\end{abstract}

Keywords: Additional building rights certificates. Urban partnership operations. Public-private alliances. Public value. Financial speculation.

\section{Certificados de potencial adicional de construção como mecanismo de financiamento das operações urbanas consorciadas ou como instrumento especulativo?}

\section{Resumo}

Este artigo apresenta as operações urbanas consorciadas (OUCs) como alianças público-privadas geradoras de valor público desenvolvidas em meio a um contexto de globalização e financeirização do mercado imobiliário, de restrições fiscais e de primazia dos interesses privados na produção do espaço urbano. Com o Estatuto da Cidade, as OUCs passam a dispor dos certificados de potencial adicional de construção (CEPACS) como principal mecanismo de financiamento. Muito contestados desde sua instituição por um possível componente especulativo de âmbito financeiro, os CEPACs - quinze anos após seus primeiros leilões - já podem ser analisados menos teoricamente e com base nos preços e volumes realizados em suas negociações. Com base nos históricos dos leilões e nas conversões das OUCs Faria Lima e Água Espraiada (ambas em São Paulo-SP), este artigo apresenta alguns avanços na reflexão sobre as possibilidades reais desse instrumento, minimizando seu caráter especulativo como correntemente previsto, e indica a necessidade de governança pública sobre as OUCs quanto à geração de valor público e à garantia do direito à cidade.

Palavras-chave: Certificados de potencial adicional de construção. Operações urbanas consorciadas. Alianças público-privadas. Valor público. Especulação financeira.

\section{¿Certificados de potencial de construcción adicional como mecanismo de financiamiento para operaciones urbanas consorciadas o como instrumento especulativo?}

\section{Resumen}

Este artículo presenta las operaciones urbanas consorciadas (OUCS) como alianzas público-privadas que generan valor público, desarrolladas en un contexto de globalización y financiarización del mercado inmobiliario, de restricciones fiscales y primacía de los intereses privados en la producción del espacio urbano. Con el Estatuto de la Ciudad, las OUCs ahora tienen los certificados de potencial de construcción adicional (CEPACs) como su principal mecanismo de financiamiento. Muy controvertidos desde su inicio por un posible componente financiero especulativo, los CEPACs - quince años después de sus primeras subastas - ahora pueden analizarse de manera menos teórica y en función de los precios y volúmenes realizados en sus negociaciones. Con base en el historial de subastas y conversiones de las OUCs Faria Lima y Água Espraiada (ambas en São Paulo-SP), el artículo presenta algunos avances en la reflexión sobre las posibilidades reales de este instrumento, minimizando su carácter especulativo como se predice actualmente, e indica la necesidad de gobernanza pública sobre las OUCs en relación con la generación de valor público y la garantía del derecho a la ciudad.

Palabras clave: Certificados de potencial de construcción adicional. Operaciones urbanas consorciadas. Alianzas público-privadas. Valor público. Especulación financiera. 


\section{INTRODUCTION}

Large urban development projects - one of the main practices advocated by contemporary urbanism - are carried out in Brazil through urban partnership operations (operações urbanas consorciadas - OUCs), an urban policy instrument used in the transformation and promotion of structural improvements in degraded and/or idle regions of cities, but with strong real estate potential. Such instrument, having as its funding strategy economic and financial partnerships between the government and the private sector, is characterized by (a) the equalization between the total cost of works and interventions and the sum of the additional building potential created by changes in legislation and (b) the anticipation of the revenue generated by the commercialization of this potential, mainly through the issuance of additional building rights certificates (certificados de potencial adicional de construção-CEPACs ).

At the initiative of city halls, OUCs create new territorial dynamics and have positive and negative impacts on the daily lives of residents and users. As great opportunities for urban development, they often respond to the demands of the real estate market for new areas of expansion, creating advantageous conditions for negotiating additional building areas for market agents, as well as for the performance of their interests in the production of space in the defined perimeters by the instrument and end up reproducing and even accentuating the socioeconomic differences in urban space.

OUCs have been planned in São Paulo-SP since 1985, changing in concept and design over time and placing themselves into the urban policy framework as an important urban policy instrument provided by the City Statute - Law No. 10257/2001 (BRASIL, 2001a). However, the OUCs in São Paulo have been proved to be ineffective in the general promotion of the right to the city - established by the City Statute - insofar as they privilege private interests active in the real estate and in financial markets, to the detriment of genuinely public interests.

In São Paulo, CEPACs were initially envisaged by the Urban Operation Faria Lima (Municipal Law No. 11732/1995) as an "innovative" mechanism to anticipate the collection of revenues, but were only launched in 2004, after their regulation by the City Statute. Since their proposition, CEPACs have been receiving praise and criticism ranging from "gold mine" to "false miracle". Technically, they were pointed out as an instrument to financialize the urban space production process and to insert yet another speculative component - with a financial nature - on the additional building potential in the perimeter of the OUCs.

After 15 years of their first public auctions and 5 OUCs with securities registered with the Securities and Exchange Commission (Comissão de Valores Mobiliários - CVM), CEPACs can now be analysed less theoretically and based on the prices and volumes made in their negotiations, seeking to question their effective use as a precise speculative financial instrument. Having as subsidies the numbers of CEPACs auctions and conversions of OUC Faria Lima and OUC Água Espraiada and the theoreticalanalytical framework with a secondary empirical basis resulting from interviews with stakeholders (STROHER, 2019), this paper examines the results of the commercialization of these certificates by São Paulo OUCs in the absence of studies on the formation, behaviour and influence of CEPAC prices.

Insofar as CEPACs, as public bonds and as a financial instrument, supposedly bring together the possibility of being used in speculative negotiations - and the possibility of affecting land prices in the perimeters of OUCs -, we sought to analyse the variations in prices and the market demand for these certificates in the public auctions of OUCs Faria Lima and Água Espraiada in the period from 2004 to 2018, evidencing, in the end, the almost non-existent trading of them in the secondary market and, because of this fact, minimizing its speculative attribute as currently foreseen.

From a broader perspective, as a specific type of public-private alliance, OUCs, with their positive and negative results, can be analysed under a new approach to public administration that goes beyond traditional and new public management. Named "new public governance" by Osborne (2006), this approach proves to be conducive to the analysis of public-private alliances and the public value generated by them (e.g., MOORE, 2007; BRYSON, CROSBY and BLOOMBERG, 2014; REYNAERS, 2014). In response to the new challenges imposed on the current networked, multisectoral, shared power society, the new public governance will reckon other values besides efficiency and effectiveness, such as public value, citizenship, democratic and collaborative governance (BRYSON, CROSBY and BLOOMBERG, 2014). 
In these terms, based on this approach to public governance as a new regime for the implementation of public policies and provision of public services and as a model for the analysis of urban public policies, we also seek to insert in this paper the theme of public value on the OUCs and on the commercialization of CEPACs as its main funding instrument.

In addition to this introduction, this paper is divided into 5 sections. In the first, we revisit the OUCs as an instrument of urban planning and a specific type of public-private alliance and present public governance and public value as analytical subsidies. In the second, we present CEPACs as the main mechanism for making OUCs viable, as well as indicate the arguments and terms about the instrument's speculation. In the third, after analysing the history of the auctions and private placements of CEPACs of the OUCs Faria Lima and Água Espraiada, we present some results of the commercialization of these certificates by the São Paulo OUCs, seeking to reflect, based on concrete data, on the existence of their speculative attribute. In the fourth, we contextualize the OUCs and CEPACs in the financialization process of the urban space. Finally, in the fifth section, we present some conclusions and general considerations about the possible speculative attribute of CEPACs and the need for public governance over OUCs in terms of generating public value and guaranteeing the right to the city.

\section{Urban partnership operations as an instrument of urban planning and a public-private alliance}

In São Paulo, since 1985, more than a dozen urban operations have been proposed and 4 of them have reached the stage of implementation: a) Urban Operation Anhangabaú/Centro1, 1991; b) OUC Faria Lima, 1995; c) OUC Água Branca, 1995; and OUC Água Espraiada, 2001. In addition to São Paulo, several other cities have already implemented or are in the process of implementing OUCs, such as Rio de Janeiro, Curitiba, Porto Alegre, Belo Horizonte, Santo André, São Bernardo do Campo and Osasco.

According to the City Statute, an urban partnership operation is an urban planning instrument composed of a "set of interventions and measures coordinated by the local government, with the participation of owners, residents, permanent users and private investors [which aims to reach, in a given predefined urban area], structural urban transformations, social improvements and environmental enhancement" (BRASIL, 2001a, art. 32, §1), differing from other urban instruments in that it refers to the structural transformation of an entire sector of a city and not just of a single land plot.

As a rule, the OUCs comprise the redesign of that sector, a set of public and private investments for the execution of works, negotiation of land use rights and obligations of building and urbanization. Normatively, the OUCs create a differentiated area from the general land use and valid occupation ordinance - given by the master plans and local land subdivision, use and occupation laws, mainly - and define a whole set of urban standards specific to their perimeters (BRASIL, 2001b).

As well as analogous large urban development projects, OUCs are fundamentally characterized by public-private partnerships and/or alliances as the main strategy of economic and financial feasibility of works and services. Public-private links have been recurrent throughout capitalist development and the formation of the modern and contemporary State. However, in the last 30 or 40 years, with the economic and managerial bankruptcy of the welfare and national-developmentalist States, a discourse with an emphasis on the great potential of private initiative - with or without profit - and public-private partnerships (PPPs) for more efficient and effective implementation of public policies and services has become hegemonic.

In Brazil, a process of substituting State action for private initiative, through the concession of public services and the privatization of state agencies and companies in several sectors of the economy, began in the late 1980s, intensified in the decade from 1990 and lasts until today². The Concessions Law (Law No. 8987/1995), the National Privatization Program (Law No. 9491/1997) and, subsequently, the PPPs Law (Law No. 11079/2004) (BRASIL, 2004), as well as the creation of regulatory agencies and several state-level programs, have been fundamental for a greater performance of the private sector in infrastructure and

\footnotetext{
${ }^{1}$ The Urban Operation Anhangabaú, the first to be implemented in São Paulo, in 1991, would be expanded in 1997 as Urban Operation Centro. However, until now, the latter has not yet been updated in accordance with the principles of the City Statute and, therefore, cannot be named an OUC.

${ }^{2}$ In the same way that the private sector has been conquering space through the privatization and concession of several economic activities in this period the third sector has also been increasingly exercising various social services in the areas of health, education, sport, culture, etc, culminating the process with the establishment of the Third Sector Legal Framework (Law No. 9790/1999), recently replaced by the New Regulatory Framework (Law No. 13.019/2014).
} 
public services projects. The OUCs, in turn, are an inherent part of this process, more specifically with regard to the insertion of the private initiative in the implementation of urban policy and the City Statute.

Public-private alliances or PPPs (as designated by the PPPs Law) can take many different forms. Graddy and Ferris (2007) working on the concepts of public-private and/or intersectoral alliances that can involve the public and private sectors (forprofit and non-profit) - point out the differences in governance structure, nature and extent of integration between partners. For these researchers, the alliances will vary from simple market contracts to mergers between organizations, and, between these extremes, they can take the forms of collaboration contract, capital alliance, alliance without share trading, with sharing of resources, expertise and administration or formation of joint ventures.

Ribeiro and Prado (2010), commenting on the PPPs Law, point out the variety that the expression "public-private partnership" has in English language, which may include: a) mixed-capital companies; b) association between state-owned companies and private companies such as consortia or joint ventures; c) privatization under the sale or sale of public goods assets; d) participation of public entities in the capital of private companies; e) operation and maintenance contracts; f) contracts for the implementation of infrastructure projects; g) concessions, licenses and franchises; h) outsourcing contracts, etc. According to the IDB (BID, 2015), instruments such as partnerships with civil society organizations, technical cooperation agreements, commercialization of government bonds and also OUCs could be added to this list.

In accordance with these many possibilities, a consolidation of the concept of public-private alliances would encompass a large number of agreements that take place around projects of common interest, projects that allow the State to share or transfer to private entities the responsibility for carrying out some functions, under the argument of greater efficiency and effectiveness ${ }^{3}$. In this sense, OUCs and CEPACs are understood as a special category of public-private alliance or distinct lato sensu PPP, once the adhesion of the private sector (owners, developers, investors, etc) by means of bonds or onerous grants of right to build ${ }^{4}$ is optional and therefore not institutionalized ${ }^{5}$.

In any case, both the OUCs and other public-private alliances and PPPs have been criticized by several institutions, social sectors and researchers worldwide, that they are not the answer to the financial constraints of the public sector nor do they deliver better services, but on the contrary, they are a costly and inefficient way to finance infrastructure, as well as to divert government investments from other public services. They also state that these companies, when making investments, seek to generate the maximum possible return and, on the other hand, to minimize their risks, which would be incompatible with the objectives of public services (LETHBRIDGE, 2014; HALL, 2015).

Such criticisms make it pertaining to use the public governance approach in the analysis of OUCs and other public-private alliances, as well as of the public value they generate or may generate and how such value is appropriated by the different stakeholders. Public governance, following the traditional public administration and the new public management, is presented as a new regime for the implementation of public policies and the provision of public services, directed and coordinated by public entities and focused on the capacity to evaluate and monitor policies and services, in the effectiveness of its results, in the transparency during the application of resources and in the sharing of this information with different agents. According to Greve and Hodge (2010), public governance contributes to public-private alliances as it emphasizes the dispersion of authority and responsibility among the various public and private actors, even though they present several challenges - which are valid in the case of OUCs - such as the management of different interests of the public, private and civil society, the complexity of project modelling, the implementation deadlines, etc.

Public value, as an analytical category for OUCs and public-private alliances in general, adds a complementary component to economic and financial modelling based solely on value for money. According to Benington (2011), the public value is defined by 2 aspects: a) the value of the "public" (in terms of products and services); and b) the value added to the public

\footnotetext{
${ }^{3}$ In contrast, stricto sensu, the PPPs governed by Law No. 11079/2004 (BRASIL, 2004) are, according to Aragão (2005, p. 18), long-term contracts "for the delegation of construction, expansion, renovation or maintenance of a given infrastructure and for the management of all or part of the administrative activities provided by through it, [...] fully or partially borne by the State, determined by reason of the quantity or quality of the utilities concretely provided by the private partner to the Public Administration or to the population".

${ }^{4}$ Another instrument of urban policy based on the created land and contained in the City Statute.

${ }^{5}$ The PPP created for the administration of the OUC da Região do Porto do Rio (Porto Maravilha), in Rio de Janeiro, is a special case that overlaps the urban planning instruments ordered by the City Statute. Therefore, although the OUCs differ, in principle, from other public-private alliances, there is nothing to prevent other arrangements from being created for the development and implementation of works and services provided for in the intervention programs of the former.
} 
sphere (in terms of broad public interest and long-term). This concept considers costs and benefits beyond monetary values, internalizing principles of equity, justice, transparency, participation and citizenship, but also operational capacity, efficiency and effectiveness. Moore (2007, p. 177), seeking to create an analytical framework for evaluating PPPs in terms of public sector negotiation, concludes that:

The work of forming public-private partnerships [...] has to be the kind that has always occurred in democratic governance: the work of associating public and private assets and aspirations to achieve purposes that are publicly valuable, through methods that are perceived as legitimate and fair, and that demonstrate to be efficient and effective.

It is worth pointing out that, in the last 3 or 4 decades, the new public management has been placed as a regime for the implementation of public policies and provision of public services, succeeding traditional public administration and imposing management techniques specific to the private sector and greater involvement of this sector in the planning and management of the State's own public activities. In a process of overcoming, the new public governance will not give up measures of efficiency and effectiveness, but will add values such as transparency, participation and accountability.

The OUCs, contemporary to the approach of the new public management, are also questioned by public governance at the same time that the society as a whole - especially technicians, researchers and populations involved - will demand efficiency, effectiveness, transparency and participation with the generation of positive public value. In this sense, it is important to clarify the role that CEPACs play in the process of financialization of urban space and, together with the OUCs, of generating public value in urban renewal projects.

\section{Additional buildings rights certificates as the main mechanism for making urban partnership operations viable and as a financial product}

Large urban projects and OUCs are, as explained, experiences of public-private alliances that have similarities and differences with regard to the role of the State and other actors in planning and management processes, in the financing models, in the distribution of costs and benefits etc. In the Brazilian model, CEPACs - replacing the instrument of onerous grant of the right to build and also based on the concept of created land - became the main funding strategy through which private investors can consort with OUCs.

CEPACs are public bonds issued by the municipality with the specific purpose of financing a specific OUC and, therefore, are necessarily linked to it. Disposed in public auctions and sold on the market ${ }^{6,7}$, or even used for the payment of works planned by the OUC, they are convertible into the right to build ${ }^{8}$ only within the perimeter defined by the OUC, and their trading is not restricted to owners of land plots and real estate in that perimeter.

According to B3 (2017), such bonds are classified as a variable income financial product that has, among other advantages:

- $\quad[\mathrm{An}]$ opportunity for investors who believe in real estate appreciation in the region targeted by the city hall's projects, given that if there is an appreciation, CEPACs are likely to be sold on the secondary market for a higher price than the acquisition;

- $[\mathrm{A}]$ flexibility in the development of real estate projects;

- Permission to build additional areas or modify the use of the property can mean a difference in the real estate projects carried out by the building companies, generating a competitive differential compared to standard properties;

- $[\mathrm{A}]$ diversity of investments in the real estate market.

However, such advantages - to be appropriated by investors and actors present in the real estate and financial markets - are not necessarily linked to the same objectives of the municipal authority or of the population residing in the perimeter of the OUC, since they can generate major changes in usage patterns or gentrification processes, for example. For the private sector,

\footnotetext{
${ }^{6}$ According to Brasil Bolsa Balcão - B3 (2017): "in the primary market, the auction procedure is generally used for the sale of the bonds by the city hall. The auction is carried out on B3's electronic trading system (PUMA Trading System). In addition to auctions, investors can purchase CEPACs in the secondary market, also through the electronic trading system PUMA Trading System".

${ }^{7}$ Brasil Bolsa Balcão S.A. is a publicly traded company supervised by the CVM resulting from the merger, in 2017, between the São Paulo Stock Exchange, Commodities and Futures (BM\&F Bovespa) and the Central Custody and Financial Settlement of Securities (CETIP).

${ }^{8}$ Each CEPAC is equivalent to a certain value per square meter, which varies by subsector according to certain stocks in additional building areas.
} 
CEPACs are a mechanism for converting building potential into marketable bonds and later converted into an additional building area used in real estate projects in the perimeter of the OUC. For the public authorities, in another sense, CEPAC's role will be to anticipate the availability of budgetary resources for investments, with the function of leveraging the OUC (BRASIL, 2001b), despite negative externalities that may impact owners, residents and users of the area in question.

Thus, at the same time that CEPACs present advantages to market players and public authorities, as noted, they would also hypothetically and potentially insert a speculative component to OUCs, since the City Statute defined such titles as of free circulation and negotiation by any person or institution, without any kind of connection with the corresponding OUC (CARVALHO FILHO, 2013) $)^{9}$. This intention is made explicit by B3 (2017) as an advantage for the "opportunity for investors who believe in the real estate appreciation of the [OUC] region" and possible sale in the secondary market. In other words, the separation between title property with potential of construction and ownership of urban land would create a "possibility" of speculative action or movement - not only in the real estate sphere, but also in the financial sphere -, since CEPACs prices (and, consequently, the right to build in the region) become dependent on both the land appreciation and the variations and movements of the bonds financial market.

As a conjunction of these last two points, Ferreira and Fix (2001) and Fix (2009) pointed out as the main danger brought by CEPACs the possibility of converting the building potential into a speculative merchandise, becoming a mechanism for capturing land added value by the holders of those securities. According to the researchers, by unlinking the title of ownership of the plot, linking it only to the building potential, it generates a possibility of financial speculation to the detriment of urban constraints. In these terms, CEPACs would eventually become a "false miracle".

Such questions were presented with certain forcefulness and diametrically opposed to the advantages of acquiring CEPACS as a financial product. However, as we will see in the next section, fifteen years after the launch of the first CEPACs, this possibility has not yet materialized, as evidenced by the formation of an insignificant secondary market for the sale and/or retention of certificates with a view to "strictly" financial speculation, since, on the contrary, most of the titles were consumed in the construction of buildings.

According to Stroher (2019), the main buyers of CEPACS from the OUCs Faria Lima and Água Espraiada were real estate developers, with the purpose of building in the areas of the OUCs (mostly national companies). That is, the first buyers were the executors of the additional building potential. As for the secondary market, it was formed as a result of errors in the calculation of the certificates account needed for the projects (above and below).

With regard to its economic sense, as indicated by the Novíssimo Dicionário de Economia (SANDRONI, 1999, p. 219), "speculation" is the process of:

Systematic purchase and sale of securities, shares, real estate, etc with the intention of obtaining fast and high profit, taking advantage of the price fluctuation. [...] consists of buying bonds or commodities when their prices are low and selling those same bonds or commodities when prices are high or reach a peak point $[\ldots]$.

In this sense, as we will see in the next section, there were no systematic purchase and sales practices for CEPACs and gains on their price fluctuations. According to data from the municipality of São Paulo, the prices of CEPACS of the OUCs Faria Lima and Água Espraiada have maintained, over time, a growth trend in both markets, with situations in which the prices of the secondary market were lower than those in the primary market (STROHER, 2019).

With this fact in mind, this paper aims only to question the movement of buying and selling CEPACs, aiming at speculative gains, which would imply their retention and over-appreciation by financial agents, as a way of artificial control of the certificates' offer. At the same time, even though we emphasize the role of CEPACs as a public-private alliance, the purpose of this paper is not to question their implications for the financialization processes of the real estate market and for the production of urban space in general.

\footnotetext{
${ }^{9}$ In a complementary way, being a public bond whose value is linked to the OUC's expectation of success, it carries with it the inherent risk of being discredited by the market and having its price devalued (SANTOS, 2004).
} 
The commercialization of additional building rights certificates in the auctions of urban partnership operations Faria Lima and Água Espraiada

In spite of the theoretical argument about the impacts of CEPACs trading in the previous section, a detailed analysis of the price behaviour of these certificates carried out over time in auctions through public offers and/or private placements by São Paulo's OUCs shows that their real appreciation is expressive (as we can see in the Graphs and Boxes below), manifesting, on the one hand, the appreciation of the land price in the perimeters of the operations and, on the other hand, the growing interest of builders and developers in certain operations - and in areas within them - more than others ${ }^{10}$.

It is worth considering that only the values of CEPACs of OUCS Faria Lima and Água Espraiada suffered such significant variations through several auctions over a period of 13 years (2004-2017). In these terms, the research was restricted to these two OUCs, since the other OUCs with CEPACs - Água Branca, in São Paulo, Porto do Rio, in Rio de Janeiro, 2009, and Linha Verde, in Curitiba, 2011 - still did not generate enough data to analyse the commercialization of CEPACs over time. In São Paulo, OUC Água Branca has been characterized, until now, by a first and only auction in 2015, with little movement, and the Urban Operation Centro has not yet issued CEPACs. In Rio de Janeiro, OUC Porto do Rio opted for a financial modelling based on the creation of a real estate investment fund by Caixa Econômica Federal, with the purchase of the entire stock of CEPACs. In Curitiba, OUC Linha Verde has not yet had a sufficient volume of sales to analyse prices over time (3.72\% of CEPACs sold in 6 auctions and $0.3 \%$ in circulation in the secondary market to date).

Thus, the minimum prices for CEPACs from OUC Água Espraiada rose from $\mathrm{R} \$ 300.00$ in the first distribution, in July 2004, to $\mathrm{R} \$ 1,261.00$ in the fifth distribution, in June 2012, showing an appreciation of $320 \%$ over 8 years. Similarly, OUC Faria Lima's CEPACs minimum prices rose from $\mathrm{R} \$ 1,100.00$ in the first distribution, in December 2004, to $\mathrm{R} \$ 6,531.01$, in the fourth distribution, in September 2017, showing an appreciation of approximately 500\% over a 13-year period. In comparison, the Extended National Consumer Price Index (IPCA) of Brazilian Institute of Geography and Statistics (IBGE) showed a correction of $51 \%$ in the first period (2004-2012) and 104\% in the second period (2004-2017). The Bovespa Index (Ibovespa) appreciated $108 \%$ in the first period and $181 \%$ in the second period.

Distinctly, OUC Água Branca would hold a single auction in March 2015, with the minimum price for CEPACs at R\$ 1,548.00, resulting in very low adhesion compared to the total distributed. Currently, a bill (PL No. 397/2018) has been discussed in the São Paulo City Council, with a proposal to reduce the minimum price by $50 \%$ and to change the conversion rate of additional building areas upwards, with the allegation that current values no longer reflect the "reality of the financial market" (MANSUIDO, 2018).

Based on these numbers, it should be noted that the injection of CEPACs in OUC Água Branca did not generate a greater interest in the operation and, consequently, a speculative interest based on future appreciations that the area came to present (or is already presenting), considering the total value of the previous revenues through onerous grant of approximately $\mathrm{R} \$ 545$ million, quite significant in the period from 1995 to 2016 , in relation to the amount of $R \$ 9,288,000.00$ held in a single CEPAC auction.

OUC Faria Lima, on its turn, presented a considerably different situation, obtaining revenues of $R \$ 465$ million through onerous grant, until 2004, and R\$ 1.454 billion through the sale of CEPACs, until December 2018, considering that the launch of CEPACs in this operation took place more than a decade before the OUC Água Branca. Distinctly, OUC Água Espraiada had no revenues via onerous grant, but only via CEPACs, raising, until December 2018, a total of R\$ 2.946 billion (SÃO PAULO, 2016a, 2016b, 2016c).

OUC Faria Lima had its commercialization of CEPACs regulated by Municipal Law No. 13769/2004 and by Municipal Law No. 13871/2004, holding its first auction at the end of that year. In spite of the failure of the first 2 auctions, in 2004 and 2006, the following auctions registered significant revenues, inserting an element of financial success in the OUC and in the commercialization of CEPACs.

\footnotetext{
${ }^{10}$ This study identified only 2 analysis references on the commercialization of CEPACs: Sandroni (2013), a working document from the Lincoln Institute of Land Policy; and Stroher (2019), a book chapter resulting from a research seminar, which demonstrates the relevance of the study.
} 
With minimum prices constantly growing and with significant premiums ${ }^{11}$, the following years (2007-2010) raised $R \$ 1,129,667,074.00$ as a result of the real estate boom that started in 2007 (Graph 1; Boxes 1 and 2). Sandroni (2013) presents the possibility that such a vertiginous growth in the demand for CEPACs would have been the result of the depletion of the portfolio of projects approved by the entrepreneurs under the old rules via onerous grant.

\section{Graphic 1}

Evolution of the values collected by the commercialization of CEPACs through public auctions and private placements (in R\$) - OUC Faria Lima (2004-2017)

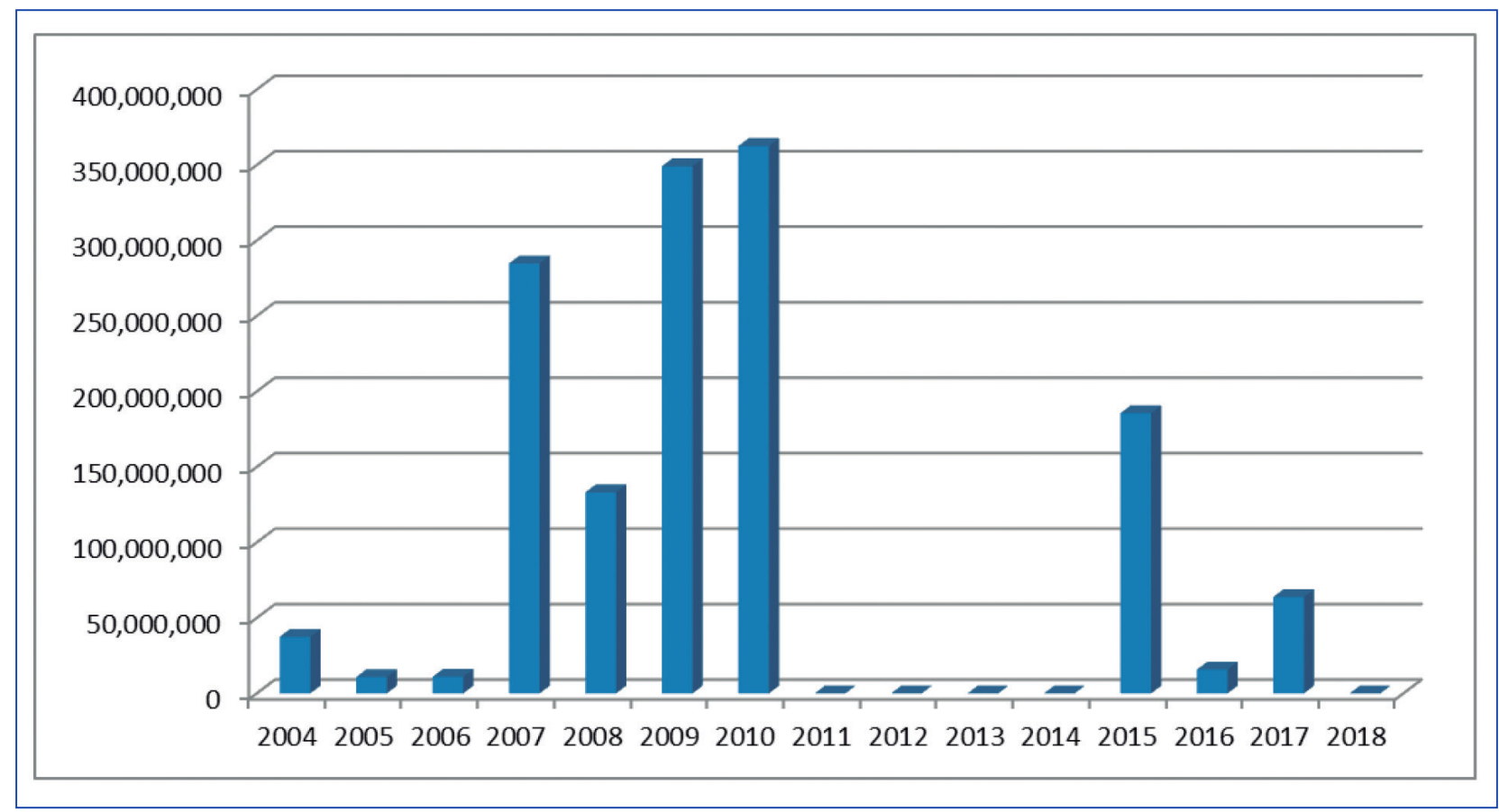

Source: Elaborated by the author based in São Paulo (2019b).

Box 1

Evolution of minimum and realized prices of CEPACs in public auctions - OUC Faria Lima (2004-2017)

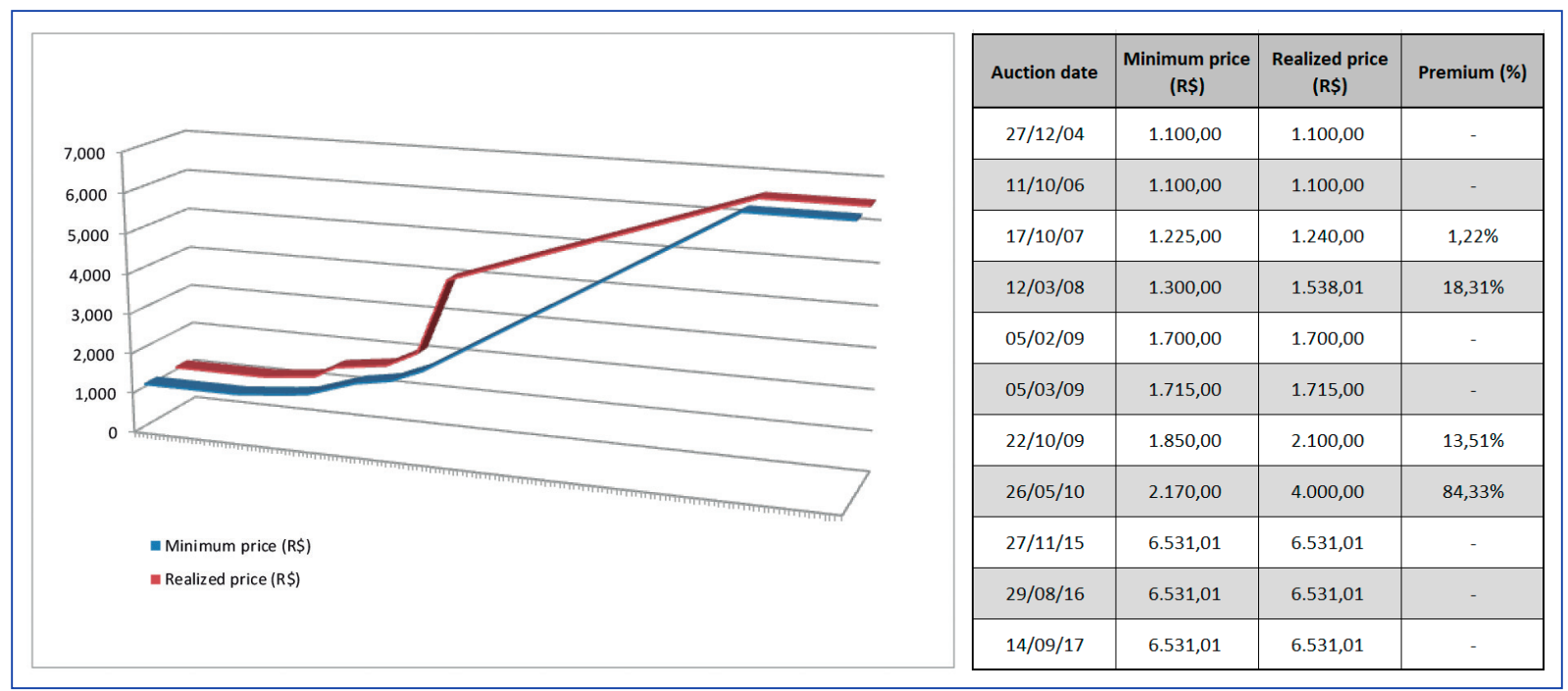

Source: Elaborated by the author based in São Paulo (2019b).

\footnotetext{
${ }^{11}$ Amounts above par values, agios.
} 
Box 2

Evolution of the number of CEPACs offered and placed through public auctions - OUC Faria Lima (2004-2017)

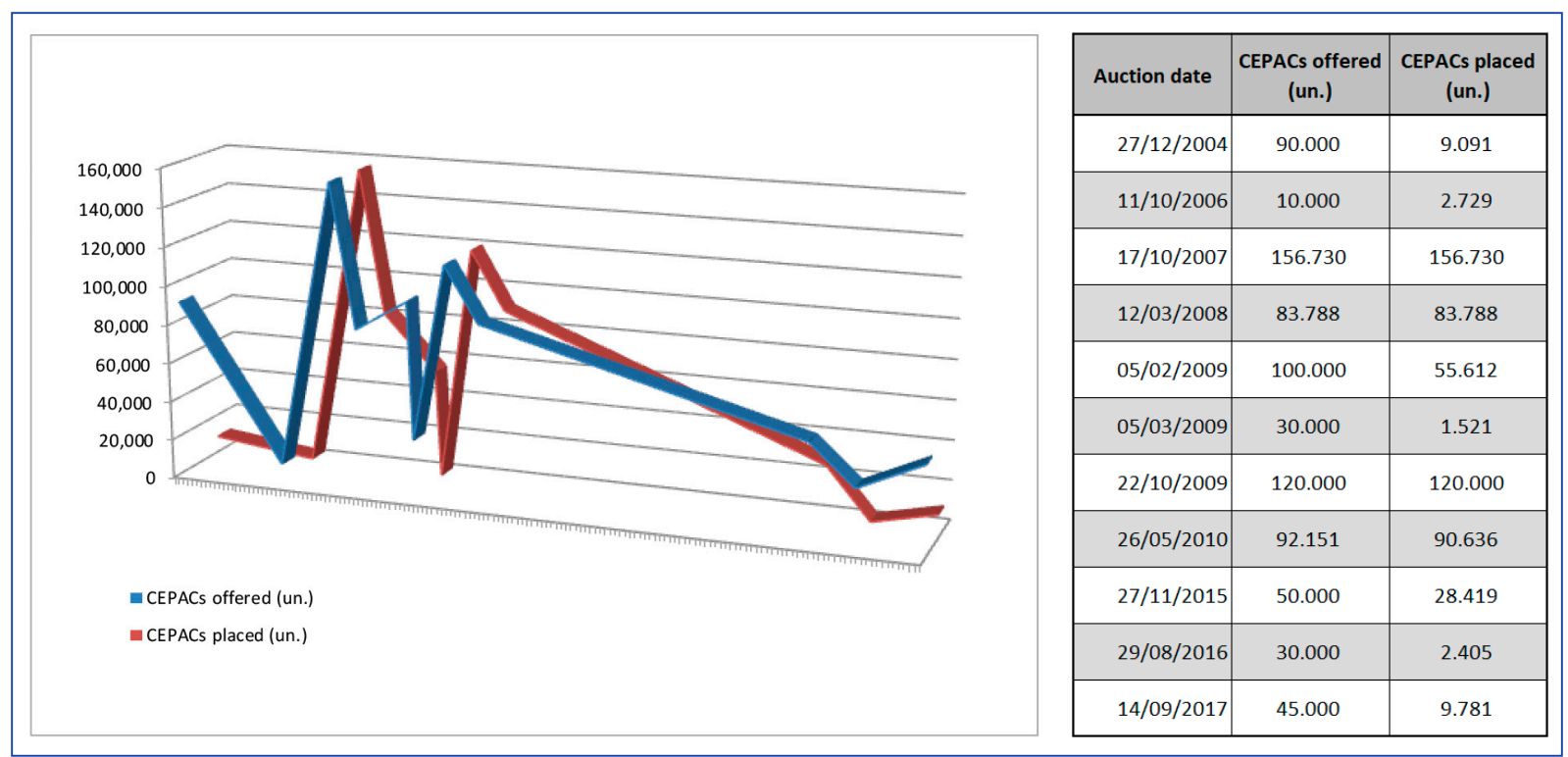

Source: Elaborated by the author based in São Paulo (2019b).

The peak of demand for CEPACs occurred in 2010, with the offering of the last 92,151 certificates in the hands of the Municipality of São Paulo, with a minimum price of $R \$ 2,170.00$ and realization at $R \$ 4,000.00$, that is, with a premium of $84.33 \%$. In this auction, the number of CEPACs planned for OUC Faria Lima would be depleted even though there was additional building potential remaining. According to Sandroni (2013), this was due to the use of CEPACs to change land use and the increase in occupancy rates. Stroher (2019), in turn, reports that, from 2012, CEPACS prices in the secondary market would rise in relation to the primary, when the total stock would have practically run out (as shown in Box 2). After this period, even with the approval by the City Council of the issuance of over 350 thousand CEPACs needed to commercialize the remaining additional building potential, the Municipality of São Paulo would only hold new auctions in 2015, 2016 and 2017, all with minimum prices of $R \$ 6,531.01$, sold without premium and with demand well below supply (Box 2).

In addition to public auctions, a significant volume of CEPACs was handled by private placements, reaching $17 \%$ of the total placed on the market. Private placements took place as contractors and suppliers agreed to receive CEPACS as payment for their works and services related to the OUC. In this modality, the prices of CEPACs would be traded at pre-established values very close to the values carried out in previous auctions, generating, until December 2018, an amount of R\$ 141 million (Box 3). In this way, it is important to point out that this modality gives CEPAC a "quasi-currency" character, generating purchasing power for the government and streamlining the execution of works and the provision of services (SANDRONI, 2013). 
Box 3

Quantitative summary of CEPACs commercialization - OUC Faria Lima (December 2018)

\begin{tabular}{|l|c|c|}
\hline \multicolumn{1}{|c|}{ Description } & Quantity & Revenue (R\$) \\
\hline CEPACs auctioned & 560.712 & $1.313 .100 .125,00$ \\
\hline Private placement & 117.452 & $140.971 .609,00$ \\
\hline Total placed & 678.164 & $1.454 .071 .735,00$ \\
\hline Converted & 641.024 & - \\
\hline In circulation & 37.140 & - \\
\hline CEPAC- Total & 1.000 .000 & - \\
\hline CEPAC- Balance & 321.836 & - \\
\hline
\end{tabular}

Source: Elaborated by the author based in São Paulo (2019b).

Based on the consolidated figures for the sale of CEPACs by OUC Faria Lima, considering that the total number of certificates currently in circulation is only $5.5 \%$ of the total placed (added auctions and private placements), with the remaining already converted (used in projects), and that, between 2004 and 2018, the sale of CEPACs in the secondary market was insignificant and always residual, it can be inferred from this operation that such bonds were not used for the purpose of speculative gains, as predicted by the aforementioned researchers and even as published by B3.

It is possible to state, as well, that the revenues provided by the price appreciation - the prices practiced, specifically suggest an appropriation of the land value added by the Municipality of São Paulo, as a direct result of the appreciation of land prices in the region. A comparison between values raised through the onerous grant with the values raised by CEPACS in relation to the consumption of additional area of construction also reveals that the added value recovered with CEPACs is approximately four times higher.

With regard to OUC Água Espraiada and the commercialization of CEPACs through auctions and private placements, this will occur - albeit concurrently with the commercialization of CEPACs by OUC Faria Lima - in a different way. As the first urban operation implemented after the City Statute and, therefore, financed solely with CEPACs resources ${ }^{12}$, OUC Água Espraiada was characterized by large proportions in relation to the others (with a perimeter of 1,400 hectares, 4,850,000 square meters of additional building area and 4,490,999 CEPAC units).

Such operation held its first auction (the first of its kind) in July 2004, followed by 15 more over 8 years, until 2012. With minimum prices ranging from $\mathrm{R} \$ 300.00$ to $\mathrm{R} \$ 370.00$ practically without addition of premium in the first 3 years after the launch of CEPACS (2004-2006), the OUC sold 45\% of the certificates offered through auctions, raising R\$102,808,720.00, which, adding up the value of private placements, represented double the values of OUC Faria Lima in the same period. In the following period, related to the real estate boom (2007-2010), OUC Água Espraiada raised, through public auctions and private placements, the total amount of $R \$ 1,103,168,492.00$, selling almost all CEPACs offered. As verified in OUC Faria Lima, in this operation, prices also rose steadily, reaching, at the end of 2010, the unit value of R\$750.00 (Graph 2 and Boxes 4 and 5).

\footnotetext{
${ }^{12}$ It is worth noting that the operation area would receive - in spite of planning and management processes - several road works, channelling of streams and removing of slums, in the previous decade, without any consideration from the benefited owners via the recovery of land value added.
} 
Graph 2

Evolution of the values collected by the sale of CEPACs through public auctions and private placements (in R\$̣) - OUC Água Espraiada (2004-2017)

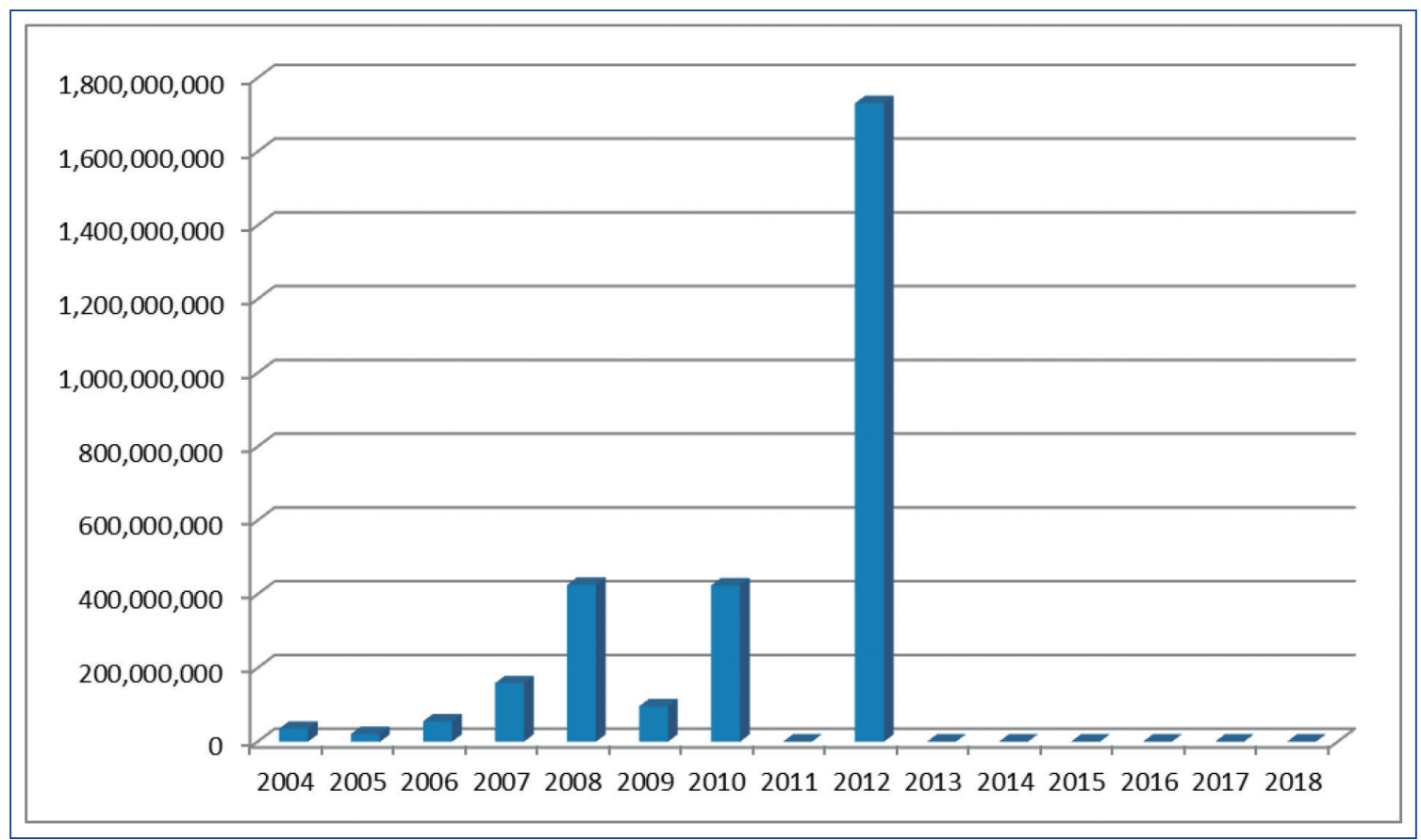

Source: Elaborated by the author based in São Paulo (2019a).

\section{Box 4}

Evolution of minimum and realized prices of CEPACs in public auctions - OUC Água Espraiada (2004-2012)

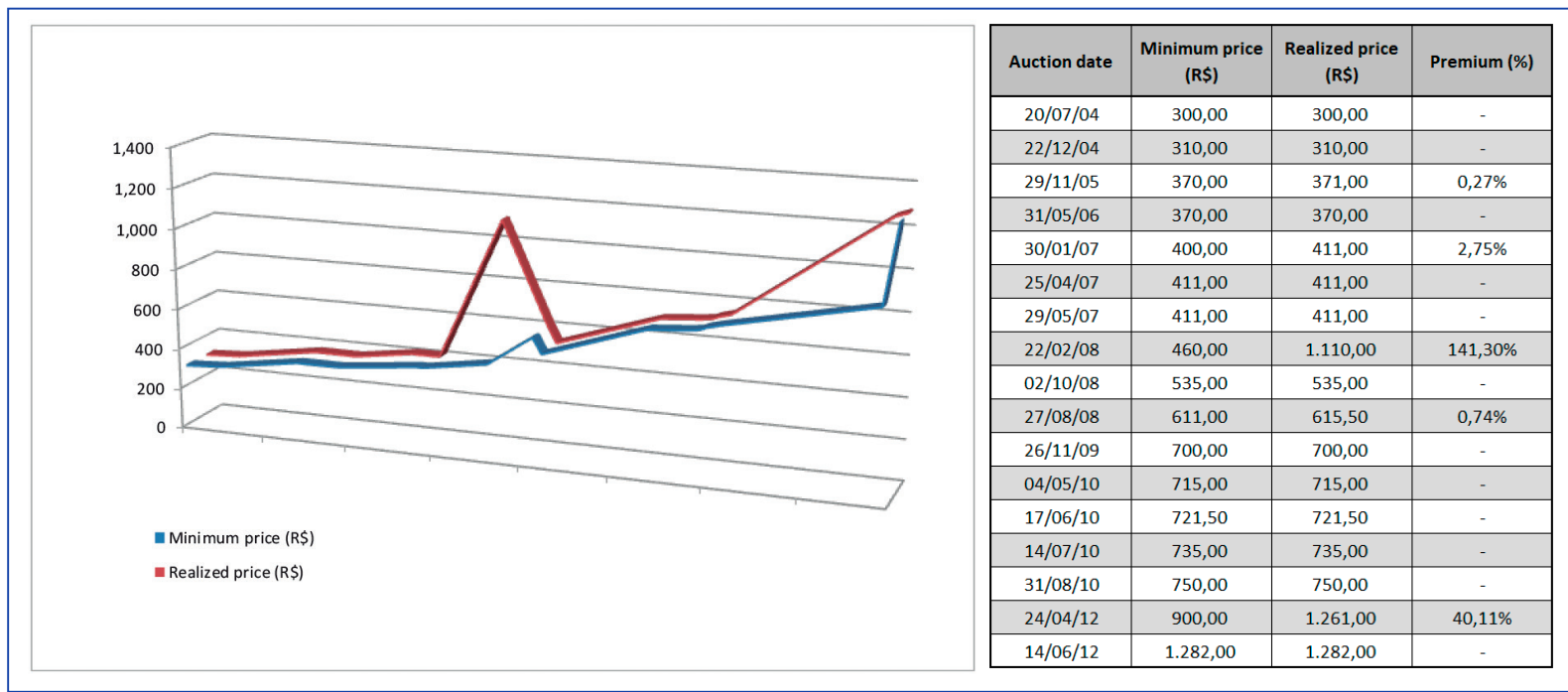

Source: Elaborated by the author based in São Paulo (2019a). 
Special attention is paid to the February 2008 auction, when - possibly in an attempt to speculate - all 186,740 CEPACS offered were purchased, applying a premium of $141.30 \%$ to the minimum price of $R \$ 460.00$ and reaching the value of $R \$ 1,100.00$, which generated a revenue of $R \$ 207,281,400.00$. As Sandroni (2013) points out, this movement would not have been successful, since in the following auction, in October of the same year, only $58 \%$ of 650 thousand CEPACs offered at the minimum price "without premium" of $\mathrm{R} \$ 535.00$ would be sold. Although the shrinkage in financing contracts and the international crisis intensified in September 2008 may have influenced the price containment, as the researcher understands, it is clear that the previous operation aimed at an artificial control of the commercialization and a future appreciation of the bonds.

Unlike OUC Faria Lima, which had its CEPACs sold out in 2010 and would only sell new CEPACs in 2015, OUC Água Espraiada reached its peak in 2012 with the sale of $80 \%$ of 1,719,339 CEPACs in just two public auctions, raising R\$1,731,353,316.00, a figure unimaginable at the time consolidated in a single year. During this period, prices would range from a minimum of $\mathrm{R} \$ 900.00$ to a realized price of $\mathrm{R} \$ 1,282.00$ (Box 4).

Box 5

Evolution of the number of CEPACs offered and placed through public auctions - OUC Água Espraiada (2004-2012)

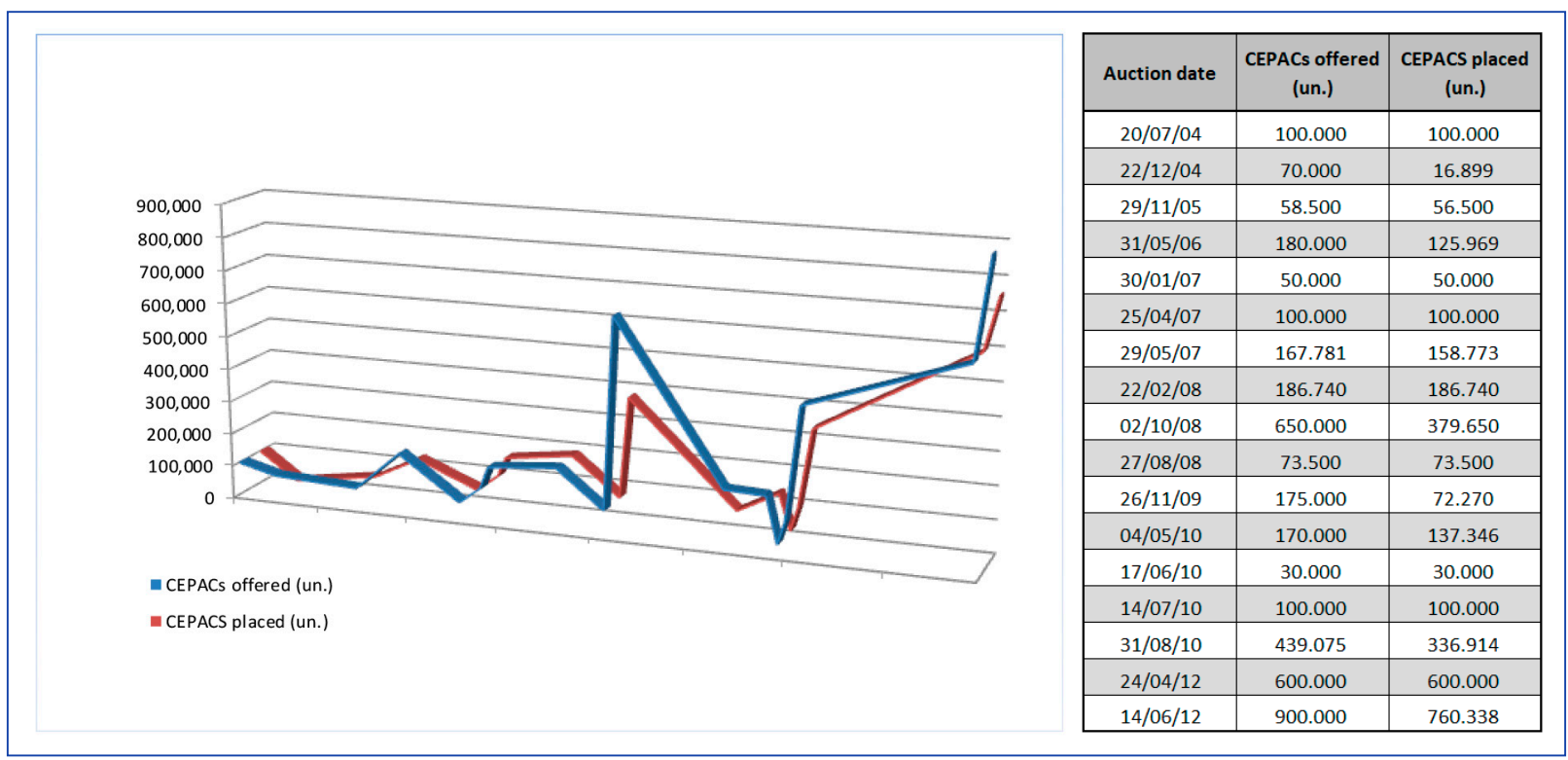

Source: Elaborated by the author based in São Paulo (2019a).

Over time, OUC Água Espraiada did not carry out a significant number of private placements for the payment of works and services, negotiating only $4 \%$ of the total CEPACs placed on the market in this modality (Box 6). On the other hand, the number of CEPACs already converted reached a level very close to the other operation studied, with only $3.29 \%$ of securities still in circulation and corroborating the thesis that they have not been used for the purpose of speculative gains, although a possible attempt has been recorded. 
Box 6

Quantitative summary of the commercialization of CEPACs - OUC Água Espraiada (December 2018)

\begin{tabular}{|l|c|c|}
\hline \multicolumn{1}{|c|}{ Description } & Quantity & Revenue (R\$) \\
\hline CEPACs auctioned & 3.254 .899 & $2.891 .275 .029,00$ \\
\hline Private placement & 136.100 & $55.030 .820,00$ \\
\hline Total placed & 3.390 .999 & $2.846 .305 .849,00$ \\
\hline Converted & 3.279 .531 & - \\
\hline In circulation & 111.468 & - \\
\hline CEPAC- Total & 4.490 .999 & - \\
\hline CEPAC- Balance & 1.100 .000 & - \\
\hline
\end{tabular}

Source: Elaborated by the author based in São Paulo (2019a).

Finally, it is worth stressing that OUC Água Espraiada still registers a $24.49 \%$ balance of CEPACs $(1,100,000$ units $)-$ i.e., not yet placed on the market - out of a total of $4,490,999$, while OUC Faria Lima registers $32.11 \%$ balance of a total of 1 million (321,836 units), noting that the initial quantity of certificates in this operation was 650 thousand CEPACs. These balances indicate that the market has not yet managed to consume the proposed stocks or has lost interest in the remaining areas.

\section{Urban partnership operations and additional building rights certificates in the process of financialization of urban space}

A new context, featured by economic neoliberalization and increased financialization and globalization, is reflected in the production, planning and management of urban space. In this context, a new school of urban planning, based on entrepreneurship, strategic planning, city marketing and spectacle urbanism has become almost hegemonic in large cities in the western world. Such "entrepreneurialism" of the public administration will make the large urban projects - the OUCs in Brazil - strongly characterized and induced by efforts of attractiveness, competitiveness and insertion of cities in the world economic system, obviously to the detriment of a service management approach, of improvement of quality of life and guarantee of the right to the city.

Whereas the economy is becoming more financialized, the real estate sector is doing so by introducing financial innovations, by increasing investments in real estate assets and by a large influx of financial capital in the production of urban space. According to Paiva (2006), this greater articulation between real estate and financial capital can be attributed to the development of new securitization mechanisms, which provide greater liquidity to permanent assets or, otherwise, a transfer of ownership of physical assets to the ownership of marketable securities in the form of shares, debentures, securitized bonds etc, creating a circuit in parallel of capital appreciation quite different from that of the sale of real assets.

As pointed out by Klink and Stroher (2017), it is important, however, that the criticisms about financialization are not limited to their results on other sectors, such as the real estate market and urban space production, but pay attention to its internal constitution and dynamics. With this in mind, in this paper, we seek to characterize OUCs as a specific urban instrument for the attainment of major urban renewal projects, whose conditio sine qua non for their economic and financial feasibility is the institution of public-private alliances, being the main one CEPACs.

CEPACs were developed with the dual function of (a) enabling the anticipation of revenue generated by the private consideration for additional building rights (a means of recovering the land value added generated by the OUCS) and (b) acting as a pricing instrument for this on the other hand, through market mechanisms resulting from the equalization of the total cost of public works and interventions, with the sum of the additional building potential provided by the operation (MALERONKA, 2015). 
In this process, CEPACs prices will be key elements, as they must balance incentives to connect landowners, builders, contractors, developers and potential investors (via financial market), while providing local governments with the necessary resources to financing infrastructure and public goods (KLINK and STROHER, 2017).

For these researchers, however, in a context of underdeveloped capital markets (e.g. Brazil), local stakeholders (consultants, planners, builders, developers, etc) would not be merely price takers, but, on the contrary, would influence the physical and financial design of the OUCs and CEPACs. In this financial engineering, such stakeholders would take into account the internal rates of return and the net present values that are financially viable for the projects planned by builders and developers.

Therefore, it is essential that OUCs, in view of the influence of stakeholders linked to the private sector in the design and implementation of instruments, develop structures and processes of public governance that guarantee the generation of positive public value with fair distribution among the parties and, ultimately, the right to the city in a more expanded way.

\section{FINAL CONSIDERATIONS}

This paper is part of two broad research agendas: a) the first on the financialization of the real estate market and the production of urban space with regard to its instruments, dynamics and impacts; and b) a second one on public governance and public value generation from public-private alliances. With this double perspective, we presented OUCs as an urban policy instrument characterized by a certain type of public-private alliance - CEPACs - that give them economic and financial feasibility to fund the necessary works and interventions, but that require public governance over the planning processes and management.

Insofar as CEPACs, as public bonds and as a financial instrument, create the possibility of being used in speculative negotiations and, because of this, they affect the price of land in the perimeters of the OUCS - as some researchers conjecture -, we sought to analyse the variations in prices and the market demand for these bonds in the public auctions of OUCs Faria Lima and Água Espraiada, in the period from 2004 to 2018, evidencing their almost non-existent trading in the secondary market.

On the one hand, it is known that CEPACs have enabled the Municipality of São Paulo (in the cases analysed) to recover exponentially greater added value than the amounts recovered by the onerous grant used before. On the other hand, it was deduced that CEPACs did not directly play a speculative role with the retention practice by their buyers for sale in the secondary market or, still, for construction in the distant future ${ }^{13}$, as can be confirmed by the high conversion rate of CEPACs in additional building area ( $96.7 \%$ by OUC Água Espraiada and $94.5 \%$ by OUC Faria Lima) and the fact that most buyers of bonds were the executors of building themselves.

In spite of the insignificant speculative inflection induced by CEPACs, the process of economic and financial globalization has been conditioning an increasing overlap between financial and real estate capital, making them more determined in search of opportunities for reproduction and accumulation and greatly influencing the production of urban space, notably through major urban restructuring projects and OUCs, more specifically, given the land prices growth in the areas of OUCs and the subsequent formal and informal gentrification processes. At the same time, it is important to note that the establishment of CEPACs made it difficult for owners and small builders to purchase additional building areas, as participation in auctions through stock brokers became necessary.

Even so, from the beginning of the use of CEPACs, the OUCs have been seen as a useful tool for the generation of large additional resources coming from the private sector, through the commercialization of additional building potential, the recovery of land value added and the most diverse types of public-private alliances, providing the local public authority with substantial financial capacity to carry out the necessary investments to finance the intervention programs established by the OUCs.

The financial results of this instrument, as shown by the experiences of the OUCs in São Paulo, can be considered successful in the medium term, as well as its urban results in terms of the building potential realized but, however, being challenged by the relative effectiveness of public benefits produced. Furthermore, by collaterally generating real estate appreciation,

${ }^{13}$ Although it is impossible to guarantee that such speculative movements will not occur significantly in the future in other operations. 
gentrification and concentration of budgetary resources in certain regions of the city, the premise of the contradiction between public interests aimed at building the OUCs and the results of the production of urban space dominated by market interests is reinforced.

Therefore, it is necessary to discuss again the terms, costs and public benefits of public-private alliances in general and the guarantee of the right to the city in the OUCs in a broader way. Likewise, it is important to continuously monitor of the appropriation of public value by public administration, private stakeholders, owners, residents and users in general, with continuous readjustment of public policies. In other words, the institution of (new) public governance as a new regime for the implementation of public policies and the provision of public services and as a model for the analysis of urban public policies, as well as the insertion of the concept of public value as an analytical category of public-private alliances in general, and the OUCs, in particular, can contribute to improving the instrument.

More than that, it is essential that citizens and actors of organized civil society start to participate more actively in the planning and management processes of the OUCS - especially in the pricing and commercialization of CEPACs - as recommended by new practices of public-private-people partnerships, with more transparency, social participation, governance and accountability, while the use of the concept of public value, with possible measurement metrics or indicators, will be of great value in the search to guarantee the right to the city.

\section{ACKNOWLEDGEMENTS}

The paper was developed as a result of doctoral and post-doctoral research funded by CAPES under contracts 88887.47989/201700 and 88882.314800/2019-01, respectively. 


\section{REFERENCES}

ARAGÃO, A. As parcerias público-privadas: PPPs no direito público brasileiro. Revista de Direito Administrativo, n. 240, p. 105-145, 2005.

BANCO INTERAMERICANO DE DESENVOLVIMENTO - BID. O investimento em infraestrutura no Brasil: parcerias público-privadas e operações urbanas consorciadas. Brasília, DF: BID, 2015.

BENINGTON, J. From private choice to public value? In: BENINGTON, B.; MOORE, M. (Org.). Public value: theory and practice. Basingstoke: Palgrave Macmillan, 2011. p. 31-51.

BRASIL. Lei n. 10.257, de 10 de julho de 2001. Regulamenta os arts. 182 e 183 da Constituição Federal, estabelece diretrizes gerais da política urbana e dá outras providências. Diário Oficial da União: seção 1, Brasília, DF, July 11, 2001 .

BRASIL. Estatuto da Cidade: guia para implementação pelos municípios e cidadãos. Brasília, DF: Câmara dos Deputados, 2001b.

BRASIL. Lei n. 11.079, de 30 de dezembro de 2004. Institui normas gerais para licitação e contratação de parceria público-privada no âmbito da administração pública. Diário Oficial da União: seção 1, Brasília, DF, Dec. 31, 2004.

BRASIL BOLSA BALCÃO - B3. Produtos e Serviços. 2017. Available at: <http://www.b3.com.br/pt_br/produtos-e-servicos/negociacao/ renda-variavel/cepac.htm>. Accessed on: Mar. 03, 2020.

BRYSON, J. M.; CROSBY, B. C.; BLOOMBERG, L. Public value governance: moving beyond traditional administration and the new public management. Public Administration Review, v. 74, n. 4, p. 445456, 2014.

CARVALHO FILHO, J. S. Comentários ao Estatuto da Cidade. 5. ed. São Paulo: Atlas, 2013

FERREIRA, J. S. W.; FIX, M. A urbanização e o falso milagre do CEPAC. 2001. Available at: <https://www1.folha.uol.com.br/fsp/opiniao/ fz1704200110.htm>. Accessed on: June 20, 2015.

FIX, M. Uma ponte para a especulação: ou a arte da renda na montagem de uma "cidade global". Caderno CRH, v. 22, n. 55, p. 41-64, 2009.

GRADDY, E. A.; FERRIS, J. M. Public-private alliances: why, when, and to what end? In: VERMA, N. (Ed.). Institutions and planning. Oxford: Elsevier, 2007. p. 175-185.

GREVE, C.; HODGE, G. Public-private partnerships and public governance challenges. In: OSBORNE, S. P. (Org.). The new public governance? Emerging perspectives on the theory and practice of public governance. New York: Routledge, 2010. p. 149-162.

HALL, D. ¿Por qué las asociaciones público-privadas no funcionan?. 2015. Available at: <http://www.world-psi.org/es/publicacion-porque-las-asociaciones-publico-privadas-apps-no-funcionan $>$. Accessed on: Aug. 22, 2017

KLINK, J.; STROHER, L. E. M. The making of urban financialization? An exploration of Brazilian urban partnership operations with building certificates. Land Use Policy, n. 69, p. 519-528, 2017.

LETHBRIDGE, J. Exposing the myths around public-private partnership. A PSIRU Briefing for EPSU. 2014. Available at: <http://www.psiru. org/sites/default/files/2015-01-PPP-EPSUPPPbriefingfinal.pdf>. Accessed on: Aug. 22, 2017.
MALERONKA, C. Análise: CEPAC é um instrumento ainda em fase de evolução. 2015. Available at: <https://sao-paulo.estadao.com. $\mathrm{br} /$ noticias/geral,analise-cepac-e-um-instrumento-ainda-em-fasede-evolucao,1614868>. Accessed on: Mar. 13, 2019.

MANSUIDO, M. Projeto que diminui valor dos CEPACs da Operação Urbana Água Branca é discutido na Câmara. 2018. Available at: $<$ http://www.saopaulo.sp.leg.br/blog/projeto-que-diminui-valor-doscepacs-da-operacao-urbana-agua-branca-e-discutido-na-camara/>. Accessed on: Mar. 03, 2018

MOORE, M. Criando valor público por meio de parcerias públicoprivadas. Revista do Serviço Público, v. 58, n. 2, p. 151-179, 2007.

OSBORNE, S. P. The new public governance? Public Management Review, v. 8, n. 3, p. 377-387, 2006

PAIVA, C. C. A diáspora do capital imobiliário e sua dinâmica de valorização no capitalismo contemporâneo: a irracionalidade em processo. 2006. 215 f. Doctoral Dissertation (Doctor Degree in Economic Development) - Universidade Estadual de Campinas, Campinas, 2006.

REYNAERS, A. M. Public values in public-private partnerships. Public Administration Review, v. 74, n. 1, p. 41-50, 2014.

RIBEIRO, M. P.; PRADO, L. N. Comentários à Lei de PPP: parceria público-privada. Fundamentos econômico-jurídicos. São Paulo: Malheiros, 2010.

SANDRONI, P. H. (Org.). Novíssimo dicionário de economia. São Paulo: Best Seller, 1999.

SANDRONI, P. H. Os certificados de potencial adicional de construção (CEPACS) como instrumento para o financiamento do desenvolvimento urbano. Cambridge: Lincoln Institute of Land Policy, 2013.

SANTOS, M. W. B. Dos instrumentos da política urbana: das operações urbanas consorciadas. In: ALMEIDA, F. D. M.; MEDAUAR, O. (Coord.). Estatuto da Cidade, Lei 10.257 de 10.07.2001: comentários. 2. ed. São Paulo: Revista dos Tribunais, 2004. p. 201-224.

SÃO PAULO. Cartilha Relatório da Operação Urbana Consorciada Água Branca. 2016a. Available at: <https://gestaourbana.prefeitura. sp.gov.br/wp-content/uploads/2016/12/OUCAB_caderno_GESTÃOURBANA.pdf >. Accessed on: Jan. 30, 2020.

SÃO PAULO. Cartilha Relatório da Operação Urbana Consorciada Água Espraiada. 2016b. Available at: <https://gestaourbana. prefeitura.sp.gov. br/wp-content/uploads/2016/12/OUCAE_caderno_GESTAOURBANA. pdf $>$. Accessed on: Jan. 30, 2020.

SÃO PAULO. Cartilha Relatório da Operação Urbana Consorciada Faria Lima. 2016c. Available at: <https://gestaourbana.prefeitura. sp.gov.br/wp-content/uploads/2016/12/OUCFL_caderno_GESTAOURBANA.pdf $>$. Accessed on: Jan. 30, 2020.

SÃO PAULO. SP Urbanismo. Histórico de leilões-OUCÁgua Espraiada: posição em 31/12/2018. 2019a. Available at: <https://www.prefeitura. sp.gov.br/cidade/secretarias/upload/desenvolvimento_urbano/sp_ urbanismo/AGUA ESPRAIADA/2019/OUCAguaEspraiada31dez18 HistoricoLeilao.pdf>. Accessed on: Mar. 20, 2019. 
SÃO PAULO. SP Urbanismo. Histórico de Leilões - OUC Faria Lima: posição em 31/12/2018. 2019b. Available at: <https://www.prefeitura. sp.gov.br/cidade/secretarias/upload/desenvolvimento_urbano/sp_ urbanismo/FARIA LIMA/2019/OUCFariaLima31dez18_HistoricoLeilao. pdf $>$. Accessed on: Mar. 20, 2019.
STROHER, L. E. M. Operações urbanas consorciadas: financeirização urbana sem investidores financeiros? In: SHIMBO, L.; RUFINO, B. Financeirização e estudos urbanos na América Latina. Rio de Janeiro: Letra Capital, 2019. p. 113-146.

Fábio José Ferraz

ORCID: https://orcid.org/ 0000-0002-4897-3608

Doctorate and post-doctorate in Urbanism from the Postgraduate Program in Architecture and Urbanism at the Pontifícia Universidade Católica de Campinas (POSURB-ARQ/PUC-Campinas); master in Urban Engineering from the Universidade Federal de São Carlos (UFSCar); Bachelor's degree in Economics from the Faculdade de Economia, Administração e Contabilidade at the Universidade de São Paulo (FEA-USP), Campinas - SP, Brazil. E-mail: fjferraz@hotmail.com

Denio Munia Benfatti

ORCID: https://orcid.org/ 0000-0002-9468-2414

Ph.D. in Urbanism and Urban Planning from the Institut d'Urbanisme de Paris- Université de Paris XII; master in Urbanism and Urban Planning from the Institut d'Urbanisme de Paris- Université Paris XII; specialization in Urban Planning from the Universidade Federal do Rio de Janeiro (COPPE/UFRJ); Graduated in Engineering from the Universidade Presbiteriana Mackenzie; Researcher at the QUAPÁ Laboratory at the Faculty of Architecture and Urbanism of the University of São Paulo (FAU-USP), São Paulo- SP, Brazil. E-mail: dbenfatti@uol.com.br 